\title{
'LIKE THE WICK OF THE LAMP, LIKE THE SILKWORM THEY ARE': STUPID SCHOOLTEACHERS IN CLASSICAL ARABIC LITERARY SOURCES ${ }^{1}$
}

\author{
Antonella Ghersetti \\ Università Ca’' Foscari, Venice
}

The alleged stupidity of schoolteachers was a common topos in $a d a b$ literature of the Abbasid period as well as in later sources. Indeed, 'the stupid schoolteacher' was a stereotype much like 'the dull person', 'the smart sponger' and 'the ridiculous bedouin'. Frequent references to such images indicate that the intended audience revelled in this kind of literary device. This article examines diverse ways of reading and interpreting the $a d a b$ sources which deal as much in fantasy as reality. Indeed, while the standard stereotypes of schoolteachers are varied, amusing and predominantly negative, they are not always as they at first appear.

'Like the wick of the lamp, like the silkworm they are': these are the words traditionally ascribed to the wise caliph, al-Ma ${ }^{\circ}$ mun, when speaking of schoolteachers. ${ }^{2}$ The quotation, from a royal authority, is related by Ibn al-Ǧawzī (d. 597/1201) in his book Ahbār al-hamqā wa-lmugaffalin (Tales of The Stupid and Simple-Minded), just at the beginning of a chapter specifically devoted to simple-minded schoolteachers (almug̈affalün min al-mucalliminn). That schoolteachers were incorrigibly fatuous was certainly a common perception, widespread in adab literature of the ${ }^{\mathrm{c}}$ Abbāsid period and in later sources too. Indeed, the question of their stupidity, or rather, the stereotype of 'the stupid schoolteacher' was a topos which several classical and post-classical writers were fond of using, along with others such as 'the dull person', 'the smart sponger' and 'the ridiculous bedouin'. ${ }^{3}$ Frequent references in

1 This article has emerged from a research seminar given at the Center for Middle Eastern Studies, University of Chicago (30 May 2008). I would like to thank Sebastian Günther of Georg-August-Universität, Göttingen and Alex Metcalfe of Lancaster University for their careful reading of this article and for their valuable remarks.

2 Ibn al-Ğawzī, Hamqāa, 134.

3 On the stereotype of 'the dull person' see A. al-Hașūṣ̂̄, al-Humq; on 'the smart sponger' see A. Ghersetti, 'À la recherche de nourriture'. The image of the bedouin in medieval Arabic literature has been carefully analysed by Joseph Sadan, "An Admirable and Ridiculous Hero": Some Notes on the Bedouin in 
the sources to these indicate that the intended audience enjoyed these kinds of literary topoi and stereotypes, and had fun in reading or listening to the stories connected to them. Being literary topics, these images should not be taken at face value - they do not necessarily reflect historical reality and at best, reflect it only to a certain extent. This must be carefully considered when reading and interpreting $a d a b$ sources where we are in the realm of representation more than of actuality.

In what ways were schoolteachers supposed to have behaved to have merited such a reputation in literature and seemingly in common opinion too? Why was their stupidity considered as some inherent characteristic? Before answering this, we must first examine the role of the $\mathrm{mu}^{c}$ allim, what he was supposed to be teaching as well as the notion of 'stupidity' in classical sources. ${ }^{4}$ In the medieval period, the term tactim (a less common equivalent is $t a^{3} d \bar{i} b$ ) referred to instruction at a basic level, and in this sense it is opposed to tadris, which referred to the teaching of religious law. Hence, $m u^{c}$ allim (and less frequently $m u^{\circ} a d d i b$ ) is the term employed for primary-school instructors who were basically Qur ānic teachers. Apart from the Qur ${ }^{\circ} \bar{a} n$, other subjects were often taught in elementary teaching, such as numeracy, poetry, grammar and philology. Ibn Haldūn (d. 808/1406) briefly illustrates the curricula of elementary education in the Arab world at his time and stresses its differences according to geographical regions. 5 Considering the conservative character of teaching in the medieval Arab world, we can take for granted that his statement has a certain validity for earlier periods too. The Qur ān was, of course, at the core of teaching in primary schools. However, while Maghribi education almost exclusively centred on it, Andalusian pedagogy focused more on reading, writing and on poetry, thus developing linguistic and literary skills using the Qur ān as a point of departure. In Ifrīqiya, there was a combined instruction of Qur ${ }^{D} \overline{\mathrm{a}}$, the hadīt as well as some simple scientific notions. ${ }^{6}$ In the East

Medieval Arabic Belles Lettres, on a Chapter of Adab by al-Râghib al-Ișfahânî, and on a Literary Model in which Admiration and Mockery Coexist', Poetics Today 10 (1989), 471-492.

4 For a brief survey on traditional schools $(k u t t a \bar{b})$ and elementary school teachers see G. Makdisi, The Rise of Colleges, 19, 83 and W. Kadi, 'Education in Islam', 7.

5 Ibn Haldūn, Muqaddima, 594-596 (The Muqaddimah, vol. 3, 301-303, chapter 6, section 38).

6 The cultural tradition in Ifrīqiyā was also marked by a keen interest in education. The first treatises showing a remarkable concern for pedagogy were 
too, children had a mixed curriculum. Primary schoolteachers there were supposed to be able to instruct their pupils in the religious sciences namely to have them learn the sacred text by heart, as well as in grammar and mathematics, even if only at an elementary level. ${ }^{7}$

In spite of the high esteem that the Prophet showed towards education and teachers, ${ }^{8}$ in later times the $m u^{c}$ allim did not enjoy general respect. In law, the oath of schoolteachers has only partial validity ${ }^{9}$ and, if we believe literary sources, the famous judge Ibn Šubruma (d. 144/761), one of the emblematic personalities at the beginning of Islam, ${ }^{10}$ did not accept the testimony of schoolmasters. ${ }^{11}$ The contempt showed towards primary-school teaching is clearly illustrated in the story reported on the authority of al-Ğāhiz: when a Qurayshī once noticed a child studying the Kitāb of Sībawayh 'he could not help exclaiming: 'Bah! This is the science of schoolteachers and the pride of beggars'. ${ }^{12}$ Al-Rāgib alIșfahānī (fl. fourth/tenth century) dedicates a section of his anthology Muhâa darāt al-udab $\bar{a}^{\supset}$ (Conversations of the Men of Letters) to the notion that teaching is considered a shortcoming for people of excellence

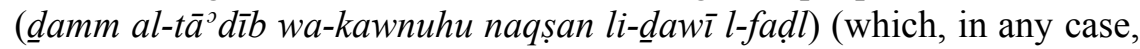
comes immediately after a section claiming the contrary - hamd al-

produced by authors such as Ibn Șạ̣nūn (d. 255/868-9), Ibn Abī Zayd (d. 386/996) and al-Qābisī (403/1012). See C. Bouyahia, La Vie littéraire, 260265.

7 For a list of the subjects covered, see S. Günther, 'Advice', 117ff. Apparently, the range of topics to be taught in traditional education had not widened in more recent times - the $m u^{\circ}$ addib al-atfăl is defined as the 'šayh of the primary traditional school $(k u t t a \bar{b})$ who teaches children the letters of alphabet...the reading of the Qur ${ }^{\circ} \bar{a} n$, writing and some mathematics'. This quotation is taken from a dictionary of traditional crafts in Damascus drawn up at the end of the nineteenth century. It also gives an idea of the wage system still in use - teachers usually received payments from the parents of their pupils. The greater the $k u t t a \bar{b}$ was, the richer (and happier) the teacher was. See S. alQasimy, Dictionnaire, 407-408.

8 See e.g. the hadīt, 'Hayru man mašā 'calā l-ardi al-mucallimūna', quoted by Ibn al-Uhuwwa (d. 729/1329), Maca àlim, 170. The hadīt is not present in the canonical collections.

9 A. Mez, Renaissance, 185 from Ibn Qutayba.

10 See J. Cl. Vadet, 'Ibn Shubruma' in Encyclopedia of Islam (2nd edition), 3: 938 .

11 Al-Ābī (d. 421/1030), Națr, vol. 5, 326; Ibn al-Ğawzī, Hamqāa, 134, on the authority of al-Ğāhiz.

12 I. Goldziher, Muslim Studies, 1: 105. 
$\left.t a^{0} d \bar{l} b\right) .{ }^{13}$ Among the evidence he cites, there is this effective poetic verse: 'It is enough as a defect for a man to be qualified as schoolmaster, even if he is excellent!' (kafā l-mar a naqșan an yuqāla bi-annahu mu allimu șibiyānin wa-in kāna fädilan). ${ }^{14}$ The same Ibn al-Muqaffa ${ }^{c}$ apparently considered it a loss of dignity for a noble person to become a schoolmaster at the end of his life. ${ }^{15}$ 'Teachers and eunuchs are of the same rank' (as well as slave-traders and the devil who are also of the same rank), is a saying ascribed to the caliph al-Walid, but the rationale of this warranted no explanation in our source. ${ }^{16}$ The general lack of prestige of this professional category is also attested in Ibn Haldūn, who claimed that in his day teaching was nothing more than 'a craft and serves to make a living [...] it is a far cry from the pride of group feeling', adding that, 'teachers are weak, indigent and rootless'. ${ }^{17} \mathrm{He}$ also explains that men in government were too proud to do any teaching, and that was why teaching came to be an occupation restricted to individuals deemed weak (al-mustad ${ }^{c}$ afin). ${ }^{18} \mathrm{He}$ claimed that, 'at the beginning of Islam and during the Umayyad and ${ }^{c}$ Abbāsid dynasties, teaching was something different. Scholarship in general was not a craft in that period'. ${ }^{19}$ Nevertheless, although he gives the impression that he somewhat idealised such ancient times, the textual evidence of other literary sources (belletristic or scientific) tells us that, even in the ${ }^{\mathrm{c}}$ Abbāsid period, $m u^{c}$ allimūn were generally despised or, at least, they were not ranked at the top of the social scale. ${ }^{20}$ The testimony of Ibn Hawqal (d. second half of the fourth/tenth century) is particularly illuminating in this respect. This famous geographer shows a total contempt for schoolmasters for whom theirs was 'the most miserable

13 Al-Iṣfahān̄i, Muḥạ̄arāt, 1: 52-53.

14 Ibid., 1: 53.

15 Ibid., 1: 52-53.

16 Ibid., 1: 459. This has perhaps to do with intellectual faculties. See pp. 92-3 below.

17 Ibn Haldūn, Muqaddima, 33 (The Muqaddimah, 1: 59).

18 Ibid., 33 (The Muqaddimah, 1: 60). The argument offered by Ibn Haldūn is that in ancient times the high dignity of teaching was based on the close link between fighting to propagate Islam and the teaching of its foundations. Once Islam was firmly established and new laws evolved, this link became ever more loose. Thus, teaching was no longer practised by the strongest (i.e. warriors or rulers), but only by weaker people.

19 Ibid., 33; (The Muqaddimah, 1: 59).

20 See A. Dietrich, 'Éducation', 97. 
position, the most humble profession, the meanest occupation' ${ }^{21}$ Since the most ancient times, he explains, the most stupid and those who did not dare to fight devoted themselves to this profession, which, out of their stupidity, they considered honourable. ${ }^{22}$

Schoolteachers, along with other professions, were routinely the subject of prejudicial remarks. As al-Tawhīìī (d. 414/1023) claimed, schoolteachers, grammarians and chancery scribes-in spite of the difference of their ranks--were equal in stupidity. ${ }^{23}$ Curiously enough, the three categories have (or should have) a thorough knowledge of language and honed linguistic skills in common. Furthermore, if by definition, weavers and cuppers were idiots, slave-traders and goldsmiths were liars, tailors were pious, ${ }^{24}$ grammarians were pedantic, ${ }^{25}$ teachers were, above all, stupid. ${ }^{26}$

But what was stupidity in the classical Arab world? In lexicographical works stupidity, humq, is usually defined as 'the stagnation of intellect', or its absence. A more problematic, but much more stimulating, definition of stupidity is that put forward in adab literature by al-Ğāhiz (d. 255/868-9, see infra) and fully formulated by the famous Iraqi writer Ibn al-Ğawzī in the work he dedicated to foolish people: 'humq is the choice of the wrong means and of the wrong way to achieve the right

21 Ahass manzila, awḍac hirfa wa-asqaț șan̄̄ a: Ibn Hawqal, Șūrat al-arḍ, 127 (Configuration, 125-126). Many passages of the chapter devoted to Sicily actually consists of an acid criticism of the intelligence, culture and ethics of its inhabitants and in particular of its schoolteachers, with a wealth of first-hand (but largely anecdotal) information about their stupidity (see for e.g. 127-130; Configuration, 126-130). Ibn Hawqal also states (129) that in his (lost) Kitāb Siqilliyya he reported all the stories he knew about the Sicilian $m u^{c}$ allimūn and their foolishness.

22 Ibn Hawqal, Sürat al-ard, 126-127 (Configuration, 125).

23 Imtā $^{c}, 1: 96$.

24 See e.g. al-Ibšīhī (d. 850/1446), Mustațraf, 1: 129-131.

25 Al-Ibšīīi, Mustatraf, 1: 518-519; a more prudish version of the anecdote at 519 in Ibn al-Ğawzī, Hamqā, 116.

26 For categories of workers generally considered stupid see al-Hașhūṣị̄, Humq, 93ff.; 95-98 for schoolteachers in particular. Another common allegation was pederasty: al-Ișfahānī, Muhāadarāt, 1: 54-55 has a section on liwät al-mu allimīn; the fact that a chapter on pederasty is extant in the Risālat al-mucallimīn of al-Ğạhiz, even if it seems to be an interpolation, demonstrates that the allegation of pederasty was common for schoolmasters. 
purpose'. ${ }^{27}$ And actually the bulk of the narrative on stupid schoolteachers turns on this very notion. All in all, cases of stupidity understood as a deficiency of the intellect or as a lack of logical abilities is quite rare. ${ }^{28}$ Most of the stories featuring stupid schoolteachers involve a distorted relationship between knowledge and appropriate behaviour.

It is worth noting that the charge of stupidity is a very serious one, since it was often defined as part of one's innate character-'a chronic disease that has no remedy' 29 - something so incurable and irreparable that even miracles cannot rectify it. ${ }^{30}$ Thus, Jesus himself must admit that he was able to revive dead and cure leprosy, but he was not able to cure foolishness. ${ }^{31}$ As an innate characteristic, it manifests itself through a number of physical traits such as a small head; a long beard (often a typical trait of schoolteachers ${ }^{32}$ ); a short neck; protruding eyes and such like. ${ }^{33}$ If these signs, based on the medical and physiognomical theories of the Greek world, are purely physical, there are also clear signs pertaining to behaviour. Stupid people are vain and loquacious; they speak out of turn; they meddle in what does not concern them. They can be recognised by careful observation, and consequently they can and should be avoided because they are harmful. ${ }^{34}$ Moreover, they must also be avoided because stupidity was potentially contagious, as reported by al-Nīsābūrī (d. 406/1015): 'stay away from the vicinity of stupid people

27 Ibn al-Ğawzī, Hamqā, 13 (see also p. 95 below). The same idea is also found in an Indian literary source: the section on foolish people (taranga 61-65 Mugdhakatha) from the Kathasaritsagara (The Ocean of Stories) of Somadeva (eleventh century CE) has some examples of this. The same for these forms of foolishness consisting in taking words at their face values.

28 One instance in al-Ābi $, N a t r, 5: 333$, where a schoolteacher is not able to calculate the difference of age between him and his brother.

29 Al-Nīsābūrī, ${ }^{c}$ Uqală $^{\circ}, 68$.

30 Al-Hașhūṣī Humq, devotes a whole chapter to this topic (127ff).

31 Ibn al-Ğawzī, Hamqā, 14; al-Ișfahān̄̄, Muhāạdarāt, 1: 15. For other sources, see A. Ghersetti 'Paradigmi', 87 n. 26.

32 See e.g. al-Ișfahān̄̄, Muhạạarāt, 1: 55; al-Fanğadīhī (d. 584/1188), $M a^{c} \bar{a} n \bar{l}$, fol. 235b-236a; al-Šarīš̄i (d. 620/1223), Šarḥ, 3: 366.

33 On the topic see A. Ghersetti, 'Firāsa'.

34 A. Ghersetti, 'Paradigmi'; al-Nīsāburī, dedicates a full chapter of his book ${ }^{c} U q a l \bar{a}^{\supset}$ al-mağānīn (Intelligent Madmen) to this topic: 'To avoid the stupid and its companionship', 67-71. 
since by being their neighbour you might become like them'. ${ }^{35}$ This is a noteworthy point. Both the idea that stupidity can be transmitted and the notion that foolishness can result from, or be comparable to, a process of consumption, are tightly bound to the stereotype of stupid schoolteachers, as we shall later see. A vivid image found in adab literature compares foolish people with worn-out clothes: neither foolish people nor worn-out clothes can be redeemed: every time they are fixed in one respect, they are torn in another. ${ }^{36}$ After all, it is an image consistent with the notion of consumption that the words of al-Ma ${ }^{5}$ mun previously quoted suggest: both the wick of the lamp and the silkworm undergo a process of gradual reduction (even if we know that in the case of the silkworm it is transformation and not consumption).

The considerable interest among medieval men of letters for the figure of the stupid schoolmaster is easily understood if we observe how this stereotype lay at the intersection of two main themes of $a d a b$ culture: intellect and knowledge, both of which are represented by their negative counterparts - stupidity and ignorance. In the Ahbār al-hamqa wa-lmugaffalīn of Ibn al-Ğawzī, the summa of materials on foolish people, the notion of stupidity and its different manifestations are widely illustrated by a considerable number of anecdotes. More significantly, it is precisely in this work that both the substantial themes of intelligence and knowledge meet. ${ }^{37}$ Indeed, the whole book is based on this thematic link. ${ }^{38}$ Fourteen out of twenty-four chapters containing anecdotes in the Ahbār al-hamqā involve idiots whose professional activity is closely related to different branches of knowledge: hadīt transmitters, grammarians, judges, chancery officers, Qur ${ }^{\circ} \bar{n}$ reciters, preachers and so forth. ${ }^{39}$ If $a d a b$ literature contains several stories in which scholars and men of science are represented as irreparably stupid, schoolteachers are by far the class of men of science in which stupidity dominates, to the point that they are considered idiots by definition. Nevertheless, Ibn alĞawzī shows a more nuanced attitude towards them and defines them as

35 Al-Nīsāburī, ${ }^{c}$ Uqală $^{\circ}, 68$.

36 Ibid., 68 and passim.

37 Al-Hașhūṣi (Humq, 35-46) puts forward the theory that in adab literature there are three levels of stupidity, and that the first, the cognitive one, is very similar to ğahl (ignorance).

$38 \mathrm{~K}$. Zakharia stresses this thematic connection in her article 'Le Savoir et ses dupes dans les Histoires des idiots et des sots d'Ibn al-Ğawzì', BEO 47 (1995), 217-233.

39 See K. Zakharia, 'Savoir', 229-230. 
mugaffalün, which means simple minded or gullible rather than stupid. As we shall see, in the end he seems to implicitly justify their intellectual deficiencies.

That schoolmasters are considered stupid by definition is a fact we can ascertain with ease simply by considering the wide range of proverbs and aphorisms on this topic. Schoolmasters very quickly become feeble minded, and they are well known for their foolishness and mental deficiency (yahrafu fì amadin yasìrin yattasimu bi-humqin șahīrin wayataqallabu bi- ${ }^{c}$ aqlin șagìirin), as stated by Abū Zayd al-Sārūğì in the 46th maqāma of al-Harīīi (m. 516/1122), al-Halabiyya. ${ }^{40}$ The chapter on the mucallimūn in the Ahbār al-hamqā of Ibn al-Ğawzī opens with the assumption that foolishness of schoolteachers 'is a matter which hardly escapes, and we see constant'. ${ }^{41}$ Other statements aim in the same direction: 'God assists [people] against the insolent and ungrateful behaviour of youngsters with the stupidity of schoolmasters': ${ }^{42}$ 'you are a tall schoolteacher with the longest beard: our Lord is enough for us and the best defence', ${ }^{43}$ and 'if you are a copyist, you are debarred from the means of subsistence, and to be stupid you need only to be a schoolteacher', ${ }^{44}$ and so on. The most representative proverb in this connection is perhaps the incisive saying, "more stupid than a schoolteacher' (ahmaq min mucallim kuttāb), ${ }^{45}$ with the variant, 'as stupid as a schoolmaster'. ${ }^{46}$ This prejudice was so widespread that Ibn Hawqal severely criticised the people of Sicily, who held schoolteachers in high esteem, in these terms: 'out of their short discernment, their scarce knowledge and absolute lack of intelligence, all the Sicilians consider this category (i.e. schoolteachers) as their most notable men, their élite.... ${ }^{47}$ Obviously, even thinking well of the $m u^{c}$ allimūn was itself a sign of stupidity, something that only people affected by unsound

\footnotetext{
40 Al-Harīīī, Maqāmāt, 384.

41 Ibn al-Ğawzī, Hamqā, 134.

42 Al-Bayhaqī (early 4/10th century), Maḥāsin, 580; al-Iṣfahānī, Muḥạạarāt, 1: 55 .

43 Al-Ișfahānī, Muhạạarāt, 1: 55. A long beard is considered the main sign of stupidity (A. Ghersetti, 'Paradigmi', 90).

44 Al-Bayhaq̄ī, Mahāasin, 580.

45 Bayān, part 1, 139.

46 A. Mez, Renaissance, 185.

47 Ibn Hawqal, Șūrat al-arḍ, 127 (Configuration, 126).
} 
intellect (as seemingly Sicilians are in the author's opinion) can do. ${ }^{48}$

Sometimes stupidity is so strongly associated with teachers as to be a genetic inheritance, for example in the case of the schoolteacher, the son of a schoolteacher, who replied when somebody asked why he was so stupid that, 'If I weren't so stupid, I'd be a bastard!' (law lam akun ahmaqa kuntu walada zinan). ${ }^{49}$ The acid test of this strong association is that in al-Harīî̀'s al-Maqāma al-Halabiyya, teaching is plainly defined as 'the profession of the inane (hirfat al-hamqā). ${ }^{50}$

But how does stupidity manifest itself in the case of schoolteachers and of what does it consist? Inappropriate behaviour, ignorance, gullibility, immorality, defects in intellectual faculties, skewed logic: all these cases are represented in the stories featuring stupid $m u^{c}$ allimün. In narratives, the stupidity of schoolteachers is multi-faceted indeed, but in most cases it relates to a distorted relationship with knowledge. It can be a glaring deficiency in the most elementary notions of mathematics as happened in the case of the $m u^{c}$ allim Abu $\overline{\mathrm{u}} \mathrm{a}^{\mathrm{c}}$ far of Hims: 'A women asked him, "If four ratl of dates cost one dirham, how many will I have

48 The foolishness of Sicilians was considered the consequence of an excessive consumption of onions which negatively inhibited the sense faculties and thus impaired the reasoning abilities of the brain (hașsyat al-bașal ihdāt fasād fì-l-dimājg, Ibn Hawqal, Șūrat al-arḍ 124; Configuration, 123). Translating Ibn Hawqal, A. Mez (Renaissance, 185) puts it in these terms "The daily consumption of onions has made the Sicilians weak-minded with the result that they see things otherwise than they are. As an illustration they regards [sic] the school-masters of whom there are more than 300, as the noblest and the most important members of their community and out of them make confidants [sic] and choose assessors in their courts. But we all know how cribbed and confined is the understanding of the schoolmasters and how light-headed they are!". Although suggestive, this is far from being faithful to the Arabic text of the Kitāb șurat al-ard: the passage is a summary of remarks that can be found in Kramers' edition at 124 (on the effect of eating onions on the mental faculties), 126 (on the great number of teachers) and 127 (on their contemptible status). These passages from the year 973, however, appear in a specific historical context in the wake of great victories against the Byzantines (which were not followed up) and the departure of soldiers to Egypt with the Fatimids. Ibn Hawqal claimed that school-teaching was a type of 'reserved occupation', attracting those wishing to shirk the call-up for the ğihād since they were exempt from fighting.

49 Ibn Qutayba (d. 276/889), ${ }^{c} U y \bar{u} n, 1.2: 64$; al-Fanğadīhī, $M a^{c} \bar{a} n \bar{\imath}$, fol. 236aа; for the hereditary character of stupidity, see al-Hुașhūṣī, Humq, 83ff.

50 Al-Harīīi, Maqāmāt, 383. 
for a dāniq and a half?" He remained pensive for a long while. Then he put his hands under the hem of his garment and began to count on the fingers. In the end he brought his hands out, joined them and exclaimed, "A lump as big as this one!", 51

Worse still, it could be crass ignorance of the rules of recitation of the Qur ${ }^{\circ}$ ān. For example, making pauses when they are not allowed ${ }^{52}$ or making wrong readings of Quranic verses, ${ }^{53}$ even worse when the teacher tries to justify his mistake. ${ }^{54}$ Stupidity could also include commenting and replying to citations from the Qur ${ }^{\circ} \bar{n}$ as if they were normal speech addressed to the teacher himself. This basically hints at the incompetence of the teachers to recognise the quotations, but it could also be taken as a sign of their inability to place matters in their correct context or, even worse, of their attitude to tinker with the sacred text. ${ }^{55}$ This last possibility is not the most remote, and relates to allegations of their dubious ethical qualities which can be found elsewhere too. Among several instances of this inability to deal with Quranic quotations, the following is particularly illustrative:

\begin{abstract}
A teacher of Medina was excessive in beating and insulting the children for which they reproached him. One day-relates the anonymous source-he asked me to take a seat with him and to see how he behaved. I sat down near to him and all of a sudden a child exclaimed ' $O$ master! 'Upon thee shall rest the curse, till the Day of Doom!' 56 Thereupon, he replied, 'And upon you and your parents!' 57
\end{abstract}

Clearly the teacher did not recognize the quotation or, even worse, if he had identified it correctly, he misses the point of the sacred text and interpreted it as a statement performed in the frame of 'normal' communication.

Another example of this behaviour, going beyond the limits of the

51 Al-Ābī, Natrr, 5: 327-328.

52 Al-Bayhaqī, Mahāāin, 579.

53 Ibn al-Ǧawzī, Hamqāa 134, 135, 136; Al-Ābī, Natrr, 5: 331; Ibn Ḥamdūn (d. 562/1166), Tadkira, 3: 285.

54 Ibn al-Ǧawzī, Hamqā, 134; al-Fanğadīhī, $M a^{c} \bar{a} n \bar{i}$, fol. 236 ; al-Šarīs̄ìi, Šarh, 3: 365 .

55 Al-Ābī, Natr, 5: 329, 330, 331-332; Ibn al-Ǧawzī, Hamqā, 136, 137; al-

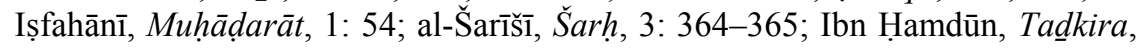
3: 285-286 n. 848, 849, 850-853.

56 Qurª̄n 15: 35, transl. Arberry.

57 al-Ābī, Natr $, 5: 329$ (similar anecdotes at 330); al-Šarišǐi, Šarh, 3: 365; a shorter version in al-Iṣfahānī, Muhāạdarāt, 1: 54. 
respect due to the sacred text, and even verging on obscenity, is that of the $m u^{c}$ allim who, instead of correcting the wrong reading of his pupil, takes it at face value and explodes with an insulting exclamation. The story goes thus: one of the pupils says innī urìdu an ankihaka ('I want to get married with you'), instead of the correct innī urìdu an unkihaka... ('I desire to marry thee [to one of these my two daughters])' ${ }^{58}$ The schoolteacher's witty retort is immediate: 'Get married with that shameless mother of yours!' (inkiḥ ummaka l-fäcila). ${ }^{59}$

Giving insulting or even obscene answers is another trait of the foolishness of schoolteachers. They also are a peculiar side of that inappropriate conduct in their duties which is so often reproached to our $m u^{c}$ allimün and which constitutes a consistent expression of humq. ${ }^{60}$ There are teachers who coarsely abuse their pupils as a means of keeping them quiet ${ }^{61}$ or when they give the wrong answer. ${ }^{62}$ But there are also lascivious schoolmasters who do not hesitate to propose sexual intercourse to their pupils' mothers, or even to have sex with them in front of their children, or to boast adulterous relations. ${ }^{63}$ This is no doubt a serious perceived shortcoming in their ethics, and it questions their dignity. This issue is likewise raised by their opportunism and servility, as shown in their disposition towards the rich and powerful. We read that a schoolteacher had the habit of having the offspring of well-off families sit in the shade, and the offspring of poor people in the sun, saying: 'Oh you people of Paradise, spit on the Hell dwellers!' 64

Otherwise, stupidity can appear as inappropriate behaviour in general or, more precisely, the kind of gap between theory and practice, between what the situation requires and what is actually done that - as we have seen earlier - is one of the definitions of foolishness in adab literature. In

58 Qur ān 28:27, transl. Arberry.

59 Al-Ābī, Naṭr, 5: 330 and 332; al-Iṣfahānī, Muhāạdarāt, 1: 54.

${ }^{60}$ In lexicography, stupidity also consists of 'putting things in the wrong place' (see A. Ghersetti, 'Paradigmi', 85).

61 Ibn al-Ğawzī, Hamqā, 135.

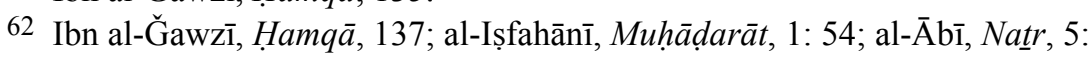
$331,332$.

63 Al-Ābī, Natrr, 5: 331, 332, 333; al-Ibšīhī, Mustatraf, 2: 520.

64 Al-Zamahšarī (d. 538/1144), $R a b \bar{t}^{c}$, 1: 522. A longer version is found in al-Šarišš, Šarh, 3: 366. Shade and sun were a sensible topic in connection with teaching and actually several hadit concern the position the teacher should avoid when teaching: the edge of the shade, or the place between sun and shade, is the place where Satan sits (see C. Melchert, 'Etiquette', 41; see also 44). 
the following anecdote, we see al-Ǧăḥiz, much to his disappointment, telling the following story:

I passed by, he says, a schoolmaster whom I found very knowledgeable. Some days later, passing to say hello to him, I found him lying on the floor like a dead man while the pupils were praying around him. I was deeply distressed, but when they finished praying, he stood up. 'What's that?' I exclaimed. And he replied 'I was teaching them the funeral prayer'. ${ }^{65}$

Interesting in relation to this is the story of the schoolteacher of a village in the countryside who, seeking to free a calf whose head was stuck in a well, first kills the calf by slitting its throat and then breaks the well by beating it with a stone. ${ }^{66}$ This serves as a clear example of the adab definition of foolishness: the purpose was right (to free the calf), but the means chosen to achieve it were wrong.

Inappropriate behaviour can also take shape as childish conduct. This happens, for instance, in the story of the $m u^{c}$ allim of Basra who refuses to address directly one of his pupils and asks another to speak to him in his place. ${ }^{67}$ Sometimes foolish behaviour is closely connected with food, and this perhaps hints at the low salaries teachers received, as in the case of the schoolteacher accused by one of his pupils to steal his breakfast ${ }^{68}$ or of another that was found crying out of despair because the boys stole his bread. ${ }^{69}$ Schoolteachers can so be equal to their pupils in their way of acting, and show a childish attitude that is inconsistent with the dignity their position requires. For instance, they can have recourse to tricks to oblige children to accomplish their school duties. The following tale tells the case of a particularly zealous schoolteacher who gives chase to his lazy pupil: al-Ğāhiz was passing by some ruins when he caught sight of a schoolteacher barking like a dog. When a boy came out from a house, the teacher slapped him and insulted him. So al-Ğāhị asked the teacher to explain that odd situation, and he replied:

This boy is a bad fellow: he hates being educated, runs away and hides himself in this house and does not want to come out. But he has the habit of playing with a

65 R. Basset, Mille et un contes, 2: 95 from Nuzhat al-udabāa ; Ch. Pellat, Milieu, 61.

66 Ibn al-Ğawzī, Hamqāa, 137; Ibn Hamdūn, Tadkira, 3: 284; other stories in al-Ābī, Natrr, 5: 327; Ibn Hamdūn, Tadkira, 3: 284 n. 843.

67 Ibn Ḥamdūn, Tadkira, 3: 284 n. 842; al-Ābī, Națr, 5: 326; al-Šarī̌̄ī, Šarh, 3: 366 .

68 Al-Ābī, Natr , 5: 327.

69 Al-Ābī, Natrr, 5: 327; Ibn Hamdūn, Tadkira, 3: 285 n. 846; Ibn al-Ğawz̄i, Hamqā 137. 
dog, and when he hears my voice he thinks it's the dog barking. Then he comes out and I seize him. ${ }^{70}$

This is an unconventional way of convincing students to attend classes, and by no means a rude educational practice, but this story also vouches for the strong commitment of teachers to their mission and can also be taken as a demonstration of their attachment to the salary families paid for the education of their offspring. ${ }^{71}$

A similar kind of childish, odd behaviour (which eventually turns out to be successful) is that of a colleague of the barking schoolteacher. AlĞāhiz is again the authority to whom the sources attribute this anecdote. One day he passed by a $m u^{c}$ allim kitted out with a short and a long stick, a polo mallet, a ball, a drum and a trumpet. When this one was asked 'What's that?' he explained: 'I have to deal with very young riffraff and when I ask one of them to read his tablet, he whistles to me breaking wind; then I strike him with the short stick and he hesitates, and when I strike him with the long one he flees from me. Then I put the ball onto the polo mallet, I beat it and I split it, and all the children stand up and come towards me with their tablets. At that moment I hung the drum up to my neck, I put the trumpet into my mouth and I start playing the drum and the trumpet. When the people of the alley hear this, they rush to me and save me from them'. ${ }^{72}$ One cannot help thinking that such a show must have offered a good reason to conjure up commonplace ideas of the stupid schoolteacher. Indeed, the equipment used, typical of infantile games, also testifies to an infantile regression so often ascribed to primary-school teachers and which is considered the main cause of their stupidity.

Of course, if we consider this kind of behaviour and the lack of concern $m u^{c}$ allimūn showed for the dignity expected from those in such positions, it is not surprising to see that many of the stories concerning stupid schoolteachers focus on the irreverent behaviour their pupils had

70 Al-Ibšīhī, Mustațraf, 2: 520; French translation R. Basset, Mille et un contes, 1: 265, n. 153, with other sources; Ch. Pellat, Milieu, 61; Ibn al-Ğawzī, Hamq $\bar{a}, 135$ with some slight variants - the teacher is hidden behind a curtain, in a royal palace, and he is on all fours.

71 The question of the teacher's responsibility for a student's attendance was closely related to the question of his salary. See, for example, what the Šăfi ${ }^{c} \overline{1}$ jurist Ibn Hağar al-Haytamī (d. 974/1567), even if in a later period, says in this connection (S. A. Jackson, 'Discipline', 21-23).

72 Al-Ibšīin̄, Mustațraf, 1: 519-520. 
towards them: teachers are slapped and beaten, ${ }^{73}$ their beards are pulled out ${ }^{74}$ their eyes are gouged with a cane $;{ }^{75}$ their food is stolen. ${ }^{76}$ This is probably a kind of ideal revenge that reflected a real habit of inflicting corporal punishment on students who were often beaten with sticks or scourges, ${ }^{77}$ figuratively represented in the anecdote featuring al-Ğăhiz's surprise to see a teacher without his usual stick. ${ }^{78}$ The disturbing thing with this kind of anecdote where, on the contrary, the $\mathrm{mu}^{c}$ allim is beaten, is that it often accepts and even justifies the abuses, for instance, by claiming that he is in debt to the boy who is slapping him, or that he will complain to his pupil's father the following day, or even that he had placed a bet with his pupils and lost. The irreverent behaviour children had towards their teachers was seemingly so common as to raise the concerns of a poor $m u^{c}$ allim who, fearing to be battered to blindness by the children who wrestle with one another in the alley, preferred to remain all alone in the kuttāb. ${ }^{79}$ If in literary sources pupils did not hesitate to be disrespectful towards their teachers, it was perhaps also because some of them had not the slightest idea about their own self-

73 Ibn al-Ğawzī, Hamqā, 136: al-Ābī, Națr, 5: 330.

74 Ibn al-Ğawzī, Hamqā, 137.

75 Al-Ābī, Națr, 5: 327; Ibn Hamdūn, Tadkira, 3: 284, n. 844.

76 See above notes 66 and 67.

77 Corporal punishments were so common that they had to be carefully regulated: no more than three cane strokes were allowed by the Ifrīqiyan Ibn Sahnūn, the author of a manual for schoolteachers who dedicates a whole chapter to this subject (French translation by G. Lecomte, pp. 81, 92, 103; some anecdotes at 81 ; on the utility of corporal punishments 87 ). The concern with abuse is also reflected in hisba manuals and legal treatises. For hisba manuals, see for instance Ibn al-Uhuwwa, Engl. transl. by R. Levy 60; Arabic text 171 ('boy] must be beaten for bad manners, insulting speech and other breaches of law'. However, 'beating must not be done with a stick thick enough to break bones, nor thin enough to harm the body, but with a medium one. A scourge with a wide thong should be used and the aim should be at the rump, thighs and lower parts of the feet, for in these places no disease or injury is to be feared'). For legal treatises, see Ibn Hağar al-Haytam̄̄'s Taqrīr al-maqāl, in S. A. Jackson, 'Discipline', 25-28.

78 Ibn al-Ğawzī, Hamqā, 135. Slaps were also part and parcel of the

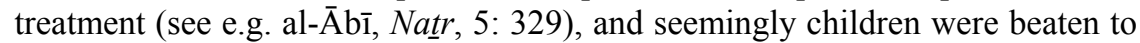
prevent them from doing wrong (Ibn al-Ğawz̄̄ Hamqā , 135-136).

79 Al-Ābī, Natrr, 5: 328, (with an anonymous protagonist); cf. Ibn al-Ǧawzī, Hamqā, 136 and al-Ibšīhī, Mustatraf, 1: 520. French transl. R. Basset, Mille et un contes, 1: 263, both with al-Ğāhiz as protagonist. 
respect and the decorum they were supposed to show. Al-Tanūhī (d. 384/994) gives first-hand evidence in this regard when in his Nišwār almuhạdara (The Table-Talk of a Mesopotamian Judge) he relates the story of a $m u^{c}$ allim who, without restraint, insults his pupils that are heaping curses on one another. ${ }^{80}$

Another facet of teachers' stupidity was gullibility. This shows itself in anecdotes featuring the poor $m u^{c}$ allim mocked by his pupils, as in the following story. Ibn al-Ğawzī relates that 'a boy proposed to the children "What about setting the šayh free today?" The children accepted and he said: "Let's go and tell him he's unwell". A child then went to him and exclaimed "I see that you are very feeble: I think you're going to run a temperature. You'd be better go home and have a rest". Hereupon, the teacher asked another child: "Your fellow says I'm sick..." and that one replied "He's right by God, and this is clear to everybody here! Ask them and they'll tell you!" The schoolmaster asked them and they testified it was true, so he told them "Go home today, and come tomorrow!" 81 .

Gullibility is also at the core of the most famous anecdotes of the series (a rather late one, since - as far as we know-it first occurs in alMustatraf of al-Ibšīhī), which portrays al-Ğāhiz as very doubtful about the real intellectual nature of schoolteachers. 'I myself-he says-wrote a treatise on anecdotes concerning schoolteachers and their carelessness (tagafful), but afterwards I changed my mind and decided to rip it up'. He explains that he happened to meet a $m u^{c}$ allim in Medina who was so accomplished in all the branches of learning that his determination to tear apart his risāla was strengthened yet further. But one day there was a catastrophe: the teacher was absent from his kuttāb, and having been informed that he was off because of a death, al-Ğāhiz decided to go and see him at his house. When he inquired about the identity of the dead (his son, his father, his brother, his wife...) the $m u^{c}$ allim gave this astonishing answer: 'My beloved'. But, much to our surprise (and to alĞāhiz's surprise as well) we discover that the poor simpleton has never met nor even seen his beloved: he simply heard a passer-by reciting some verses praising the beauty of a certain Umm ${ }^{\mathrm{c}} \mathrm{Amr}$, and he fell in love with her. And when the same passerby recited some verses announcing her departure, he understood that she was dead, left his kuttäb disconsolate and remained at home. Hearing all this, al-Ǧăhiz exclaimed: 'Oh man, I wrote a book about your stories, you schoolteachers, and

80 Nišwār, 3: 148.

81 Ibn al-Ğawzī, Hamqā, 135; for other stories see also 136-137 and al-Ābī, Natr, 5: 329, 331. 
when I met you I decided to tear it apart. But now, I'm more than ever resolved to keep it, and furthermore I'll begin just with you' ${ }^{82}$

This story enjoyed remarkable success as its several occurrences testify, since we also find it, with some slight variations, in The Thousand and One Nights in both the Būlāq and Beirut editions. ${ }^{83}$ In this latter version, al-Ğāhiz is replaced by an anonymous 'outstanding man' ( $b a^{c} d$ al-fudala $\bar{a}^{\supset}$ ), and the sciences ( $q i r \bar{a}^{\supset} \bar{a} t, n a h w, \check{s}^{c} r$, luga), knowledge of which was considered necessary for a teacher, are accurately listed - itself of importance for the history of education. But the most relevant variation of The Thousand and One Nights version is the explicit admission of the mental deficiency of schoolmasters: 'Intelligent people all agree on the mental deficiency of teachers of primary school', boldly says the anonymous source relating the anecdote. This statement then leaves no room for doubt: by general consensus, $m u^{c}$ allimūn are most definitely idiots. ${ }^{84}$ Incidentally, among the droll stories on idiot $m u^{c}$ allimūn that are found in The Thousand and One Nights, the anecdote which immediately follows this one relates how a schoolteacher emasculated himself having incorrectly evaluated the usefulness of his testicles. Needless to say, this one has been curiously neglected in the expurgated Beirut edition of the Jesuits. ${ }^{85}$

Al-Ğāhiz is present in many of the anecdotes we have mentioned, but, and this must be stressed, only in later sources. The several anecdotes linked to al-Ğāhiz which Ibn al-Ğawzī includes in his Ahbār al-ḥamqā do not actually show any connection with the famous ${ }^{\mathrm{c}} \mathrm{Abbasid}$ writer when quoted in earlier works. Thus, we can safely maintain that the attribution to al-Ğāhiz of the bulk of anecdotes about ridiculous teachers is a somewhat late phenomenon dating from the sixth/twelfth century This could well be the consequence of the fame of his Kitäb almucallimin.

82 Al-Ibšīhī, Mustatraf, 1: 520-521; French transl. R. Basset, Mille et un contes, 1: 415-417 quoted by Ch. Pellat, Milieu, 60-61; Ibn Hịğğa, Tamarāt, 402-403.

83 Alf layla, ed. al- ${ }^{\mathrm{c} A d a w i ̄, ~ 1: ~ 583-584 ; ~ A l f ~ l a y l a, ~ e d . ~ B e i r u t, ~ 3: ~ 78-79 . ~ S e e ~}$ also V. Chauvin, Bibliographie, 6: 136.

84 That is exactly what Ibn Hawqal stated, even more emphatically, some centuries earlier: wa-bi-iğmāci minhum wa-min kulli insānin anna l-mucallima ahmaqu mahkūmun calayhi bi-l-naqși wa-l-ğahli wa-l-hiffati wa-qillati al- ${ }^{c} a q l$. (Sürat al-ard, 127; Configuration, 126).

85 The catalogue of stories on the schoolteachers in the Thousand and One Nights is found in V. Chauvin, Bibliographie, 6: 136-138, nn. 287-292. 
The following story illustrates al-Ǧăhiz's reputation as the author of such a treatise: 'They say that a schoolteacher went to al-Ğāhiz and asked him if he was the author of the Kitāb al-mucallimin in which he had blamed them. When he answered in the affirmative, the man continued: 'And you mentioned in it that a teacher went to a fisherman and asked him what he was fishing for, fresh or salty game?' 'Yes, that's right', replied al-Ǧăhiz. The man thereupon exclaimed: 'That fellow was an idiot! Had he been intelligent, he would have stayed and seen, and he would have known if what was coming out was fresh or salty".'86

However, as in the anecdote we quoted previously, in which al-Ǧăhiz himself features presenting his famous risāla as a stern criticism of stupid schoolteachers, this story shows a distortion of both the real contents of his treatise and his opinions as well. We are clearly in the realm of representation, if not of fancy. The attribution to al-Ğāhiz of the anecdotes where he plays the role of protagonist, the pretension that they were taken from his risâla on schoolteachers and, last but not least, the allegation that he was in the end deeply convinced of the stupidity of schoolteachers, are not supported by textual evidence. In the 1950s Ch. Pellat wondered if the attribution of all these anecdotes to al-Ğāhị was a legend, and noticed that his risāla contained none of the stories later quoted on his authority. He even forwarded the hypothesis that there were two drafts of the same treatise. ${ }^{87} \mathrm{~A}$ few decades later some of the doubts have found an answer, and since then two critical editions of the Kitāb al-mu ${ }^{c}$ allimīn have been published, one by ${ }^{c}$ Abd al-Salām Hārūn ${ }^{88}$ and the other by Ibrāhīm Ğirīs. ${ }^{89}$ The extant text of the risāla, unfortunately very fragmentary, bears no trace of the amusing anecdotes on stupid schoolmasters which the tradition ascribes to al-Ğăhiz, and which were supposed to exist in his work. Furthermore, the opinion that he had a negative attitude towards this category of people, an opinion

86 Ibn al-Ğawzī, Hamqā, 136.

87 'On doit se demander si l'attribution à Ğāhịiz de toutes ces anecdotes ne contient pas un fond de vérité ou si, au contraire, elle relève de la pure légende' (Ch. Pellat, Milieu, 61) and 'Il semble bien que la risāla sur les mucallimūn ne contienne rien de ce que les auteurs d'ouvrages d'adab nous laissent espérer. Y a-t-il deux rédactions de cette risāla? Où les auteurs ont-ils puisé les anecdotes qu'ils reproduisent? Un écrivain postérieur a-t-il attribué à Ğāhiiz une risāla de sa composition? Autant de questions qui restent pour l'instant sans réponse' (Ch. Pellat, Milieu, 62).

88 In Rasā̄il al-Ğăhiz, part 3, 27-51.

89 In Kitābān li-l-Ğāhiz, 58-87. 
widely spread in ancient sources (e.g. Ibn al-Ğawzī, al-Šarīšs̄, al-Ibšîhī,) and in modern scholarship as well, turns out to be wrong. ${ }^{90}$ Even the hypothetical existence of a treatise on the blame of schoolteachers, a Risāla fi damm al-mu allimīn, has not been proved up to now.

Surprisingly, if we compare it with the image conveyed by the anecdotes we have analysed, the Kitāb al-mucallimin is far from a celebration of the commonplace notion of the 'idiot teacher'. On the contrary, it 'deals, from a literary-philosophical point of view, with questions of learning and teaching at the more advanced levels', ${ }^{91}$ and thus constitutes a manifest praise of the role of schoolmasters in society. ${ }^{92}$ The epistle of al-Ǧāḥiz had a wide renown among literati, as we have seen. Several anecdotes circulating in $a d a b$ literature feature the genial writer, hinting at his risāla, and commenting on its validity and contents. But this is part and parcel of the process of representation so typical of $a d a b$ literature, and does not necessarily correspond to a factual report. For sure, if al-Ğāhiz mentioned the common observation of the stupidity of schoolteachers, it was merely to dismantle it, as it already had been in the Kitāb al-bayān wa-l-tabyīn (The Book of Clear and Eloquent Exposition). The pages he dedicates to the topic in this work open with the quotation of the saying ahmaqu min mucallimi kuttāb ('more stupid than a schoolteacher'), that al-Ğāhiz qualifies as 'popular' ( $\min$ amtāl al- $\left.{ }^{c} \bar{a} m m a\right)$. This is followed by a famous line of poetry ascribed to Șiqlāb al-Mư allim:

How can you hope to find intelligence and sensibility in / those who go back and forth with women and children. ${ }^{93}$

Precisely the same idea was widespread in other adab works. For instance, as we find it in an anonymous verse quoted by one of alĞāhiz's epigones, al-Bayhaqī but this time set in a dubitative tone:

Do those who always go back and forth with / women and children acquire intelligence? ${ }^{94}$

Stupidity then seems to be a deficiency which is not innate in the nature of men, but can be contracted by associating with some categories of

90 For a discussion of this, see I. Ǧirīs, Muqaddima, in Kitābān, 29-30.

91 S. Günther, 'Be masters', 371-372.

92 Summary and partial translation of this treatise in S. Günther, 'Advice', $114-125$.

93 Bayān, part 1, 139; Ibn Qutayba, ${ }^{c} U y \bar{u} n, 1.2$ : 64; al-Iṣfahānī, Muhāạarāt, 1: 55; al-Zamahšarī, $\operatorname{Rabi}^{c}, 1: 517$.

94 Al-Bayhaq̄ī, Maḥ̄āsin, 580. 
people who are foolish by nature, namely women and children. This is testified by the advice of wise men that al-Ğāhiz quotes in connection with the proverb mentioned above. A wise man, he says, told that 'you are never to ask a schoolteacher for advice, a sheep herder or somebody who associates with women'. 95 Obviously, being in contact with children, sheep and women has a bad effect on the intellectual faculties of men.

Nevertheless, there is seemingly a hierarchy in foolishness: "the intellect of one hundred schoolmasters is equivalent to the intellect of a woman, that of one hundred women is equivalent to that of a weaver, that of one hundred weavers is equivalent to that of an eunuch and that of one hundred eunuchs is equivalent to that of a child'. The sources consulted attribute this saying to al-Ǧăhiz, but of course there is no such statement in al-Ǧāhiz's works on schoolmasters. ${ }^{96}$ It is perhaps worth stressing that, in this case, the lowest rung of the social ladder belongs to schoolteachers - even if women come immediately after. But it is more usually women who have this honour. The same 'wise' man mentioned earlier goes on to explain how, 'You must never let the mother of your son beat him, since he is more intelligent than her, even if she's elder' ${ }^{97}$ This superstition about feminine intelligence dies hard if a later author, Ibn al-Ğawzī, attributes to women the lowest position in the hierarchy of intelligent people. In his Ahbār al-adkiy $\bar{a}^{\jmath}$ (Tales of The Sagacious) he divides people into ranks, ordered from top to bottom: women are placed in the penultimate chapter, just after children and the insane, but thankfully before animals. In any case, the kind of acquired stupidity deriving from mixing with the weaker sex must not worry men too much. The caliph al-Ma ${ }^{3}$ mūn again has something to tell us: if men are affected by flippancy ( $\left.r u^{c} \bar{u} n a\right)$ because of their habitual visiting of women, it is enough for them to stop associating with them and to associate with real men ( $f u h \bar{u} l$ al-riğ $\bar{a} l)$ to put an end to this flaw. ${ }^{98}$

These are the commonplace views al-Ğāhiz had to deal with; but, as always, he was not ready to accept clichés. Indeed, immediately after

95 Al-Ǧāḥiz, Bayān, part 1, 139.

96 Al-Fanğadīhī, $M a^{c} \bar{a} n \bar{l}$, fol. 236 a ; al-Šarī̄̌ì, Šarh, 3: 364. A variant, quoted in both sources is that 'the intellect of two perfect women is equivalent to that of a man; that of four eunuchs is equivalent to that of a woman; that of forty weavers is equivalent to that of an eunuch; and that of forty schoolteachers is equivalent to that of a weaver'.

97 Bayān, part 1, 139.

98 Ibn al-Ğawzī, Hamqāa, 15. 
these quotations, he begins to deconstruct them. The first category he tackles is that of shepherds: people cannot claim on good grounds that shepherds are foolish, since many prophets practised precisely this job. This is, of course, a good reason to refute their imagined stupidity. ${ }^{99}$ Then he passes to schoolteachers, and demonstrates why it is completely unreasonable to consider them idiots. There are two categories of masters, says al-Ğāhiz: those who ascended from the education of common people's offspring to educating the elite's offspring, and those who ascended from educating these to educating royal offspring, who were themselves candidates for the future caliphate. ${ }^{100}$ Among them are such personalities as al-Kisā $\bar{a}^{-} \bar{l}$ and Qutrub, both famous and revered grammarians. Incidentally, al-Ğāhiz himself was appointed by alMutawakkil as tutor of his sons, 'but, on seeing me-he relates-he disliked my looks and dismissed me with a present of ten thousand dirhams'. ${ }^{101}$ Not such a bad an experience, one might think. But how could these people, al-Ğāhiz goes on to say, be reasonably called stupid (hamqa) ? This is inconceivable, for them and for those who are staying on the lower rungs as well, such as the primary school (kuttāb) teachers living in the countryside villages. Al-Ğăhiz continues to offer numerous concrete examples of revered scholars and literati who were also teachers, such as Ibn al-Muqaffa ${ }^{c}$ and ${ }^{\mathrm{c}} \mathrm{Abd}$ al-Hamīd al-Kātib. Even the redoubtable governor al-Hağğăğ b. Yūsuf worked as $m u^{c}$ allim, and his father as well, both in al-Ṭāif. Interestingly, this same argument- that is, to have been a schoolteacher-is used by his denigrators to belittle alḤăğğāğ. ${ }^{102}$ But al-Ğāhị goes beyond this and adds his personal experience to the long list of historical cases. Among his associates in Basra he knew no one more acquainted with the sciences and more eloquent than two schoolteachers called Abū l-Wazīr and Abū ${ }^{c}$ Adnān, both of whom figured among his first childhood memories. 103 Unfortunately, we must point out that the third category mentioned in the proverb quoted earlier - 'you are never to ask a schoolteacher for advice, a shepherd or somebody who associates with women' i.e. 'those who

99 Bayān, part 1, 139.

100 Ibid., 139 (the passage is reported also by al-Ișfahān̄, Muhāẹarāt, 1: 55).

Some of the most famous 'royal' schoolteachers are presented in A. Dietrich, 'Éducation'; as the author underlines, the tutors were mostly philologists and transmitters, but there were also poets and musicians.

101 Ibn Hुallikān, Wafāyāt, 2: 405; A. Dietrich, 'Éducation', 95 n. 3.

102 A. Dietrich, 'Éducation', 97.

103 Bayān, part 1, 140-141. 
associate with women'-is not taken into consideration and, in fact, there is no refutation of the stupidity of women.

In this respect, another proverb comes to our rescue, partially reassuring us about the misogyny of the classical Muslim world. This time, stupidity is considered as an intrinsic feature of weavers, spinners (of yarn), and again, of schoolteachers (al-humqu fi-l-hākati wa-lmucallimina wa-l-gazzālīn). However, women who are so often mentioned in this vein, are ignored. While al-Ğạhiz hastens to deny this statement for schoolteachers, as we have seen earlier, he takes a different position towards the other two categories that are considered far less than stupid. If one defines stupidity, as al-Ğăhiz does, in terms of the slippage between thoughts and actions (the foolish person is the one who thinks well but acts wrongly, or "who speaks well and correctly, then makes a monstrous mistake') ${ }^{104}$, then weavers and spinners are beyond even stupidity, since they are neither able to act well, nor to speak well. If this is the view taken by al-Ğạhiz in al-Bayān wa-l-tabyin, the perusal of the extant passages of his Kitāb al-mucallimin -where the popular saying 'more stupid than a schoolteacher' is not even mentioned-does indeed confirm his attitude towards primary-school teachers: the topic of foolishness is not dealt with, and the stereotype of the stupid schoolteacher is even not hinted at.

It is clear from what precedes, that this cliché, apparently so widely accepted by the wider population, was resolutely rejected in the case of al-Ğāhiz, who vouched for the excellence of the $m u^{c}$ allimūn. In a later source, the Ahbār al-hamqā of Ibn al-Ğawzī, the same stereotype, if not rejected, is somehow mitigated and even justified. Let us reconsider al$\mathrm{Ma}^{\circ}$ mūn's speech related at the beginning of the chapter on schoolmasters from which we have taken the sentence that opened this article. The wise caliph precisely says:

What do you think of someone who polishes our intelligences with his good manners ( $a d a b)$, and whose intelligence becomes rusty because of our ignorance, who honours us with his assured knowledge and whom we disdain with our frivolity, who stimulates our minds with his useful lessons, consumes his mind with our errors, does not give up resisting our ignorance with his science, our carelessness with his vigilance, our deficiency with his perfection until we are immersed in his praiseworthy qualities and he sinks into our blameworthy qualities and whenever we have the maximum of profit, he has the maximum of stupidity, whenever we are adorned with the more venerable manners, becomes completely idle. Since we forever deprive him the good manners he had acquired, and acquire them without him, and enter into him

104 Bayān, part 1, 140. For this concept see A. Ghersetti, 'Paradigmi'. 
our innate natural dispositions that he acquires alone without us. All his life long he makes us acquire intelligence, while he acquires our ignorance: that's why he's like the wick of the lamp and like the silkworm. ${ }^{105}$

How can we best evaluate this, a true praise of the function and role of schoolteachers? Here stupidity of teachers appears as the result of a process of consumption, a kind of wear and tear, or a type of contagion rather than an innate defect and incurable illness. ${ }^{106}$ Actually, Ibn alĞawzī through the quotation of al-Ma ${ }^{\circ}$ mūn's words again takes the explanation that al-Ğāhiz had hinted at, and in the end justifies the $m u^{c}$ allimūn: if teachers are stupid, they are not stupid by nature. On the contrary, they become stupid because of the intimate association with children who, on the contrary, do seem to be stupid by nature. ${ }^{107}$ Or, still better, they slowly lose their intelligence, wearing it out in the service of their pupils: a sacrifice that ultimately consecrates schoolmasters as missionaries, or indeed, as martyrs of education. Observable here is the huge gulf between this and the perfect idiots that the literary tradition portrays. Not perhaps a great compliment for their pupils, but a great recognition of the poor and much maligned $m u^{c}$ allim.

\section{BIBLIOGRAPHY}

\section{Primary Sources}

Al-Ābī, Natr al-durr, ed. Muhammad ' Alī Qarna et al., 7 vols (Cairo: alHay ${ }^{\circ}$ a al-Mișriyya al- ${ }^{\mathrm{C}} \overline{\mathrm{A}} \mathrm{mma}$ li-1-Kitāb, [?]-1990).

Alf layla wa-layla qad had̦dabahu wa-ṣaḥhahahu aḥad al-ābā ${ }^{\supset}$ alYasū $\bar{c}^{\mathrm{c}}$ yȳ̄n, 5 vols (Beirut: al-Mațba ${ }^{\mathrm{c} a}$ al-Kātūlikiyya, n.d.).

Alf layla wa-layla, ed. Muhammad Qițta al- ${ }^{\mathrm{c}}$ Adawī, 2 vols (Baghdad: Mațba ${ }^{\mathrm{c}}$ at al-Mutannā, n.d., repr. Būlāq).

Al-Bayhaqī, Ibrāhīm b. Muḥammad, al-Mahāasin wa-l-masāwi’ (Beirut: Dār Șādir, 1390/1970).

Fahd, Toufiq, 'Les corps des métiers au IV/X siècle à Baghdad d'après le

105 Ibn al-Ğawzī, Hamqā, 134.

106 In the same vein is the commentary al-Fanğadīhi makes on the final words of the 46th maqāma of al-Harīin. He clarifies the passage saying that the intellect of schoolteachers becomes as small as that of children, quoting also the following verse: 'a child, equal to his teachers in ugliness/and his teachers, equal to children in intellect' $\left(M a^{c} \bar{a} n \bar{\imath}\right.$, fol. 236b).

107 Ibn al-Ǧawzī, Hamqā, 134. 
chapitre XII d'al-Qādirī fì-l-ta'bīr de Dīnawarī', Journal of the Economic and Social History of the Orient 8 (1965), 186-212.

Al-Fanğadīhī, Ma $a^{c} \bar{a} n \bar{l}$ al-muqāmāt fì ma $a^{c} \bar{a} \bar{\imath}$ al-maqāmāt, ms Escurial arabe 494.

Al-Ğāḥiz, Kitāb al-mucallimīn, in Kitābān li-l-Ğāhhiz, ed. and

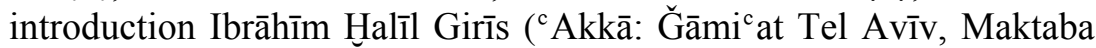
wa-Mațba ${ }^{c}$ al-Sarūğ̄̌, 1980).

Al-Ğāhịiz, al-Bayān wa-l-tabyīn, 3 vols in 1 (Beirut: Dār al-Kutub al${ }^{c}$ Ilmiyya, n.d.).

Al-Ğāhiz, Rasāo il al-Ǧăhiz, ed. ' A. S. Hārūn, 4 vols (repr. Beirut: Dār alĞîl, 1441/1991; or ed. 1964-79).

Al-Ḥarīrī, al-Maqāmāt, šarḥ wa-tahquīq Y. Biqā̄î̄ (Beirut: Dār al-Kitāb al-Lubnānī, n.d.).

Ibn al-Ğawzī, Ahbār al-ḥamqā wa-l-muġaffalīn (Beirut, Dār al-Kutub al${ }^{\mathrm{c}}$ Ilmiyya, 1405/1985).

Ibn Hallikān, Wafayāt al-a $a^{c} y a \bar{n}$, Engl. transl. Mac Guckin de Slane (Ibn Khallikan's Biographical Dictionary), 4 vols (repr. New York and London: Johnson Reprint Corporation, 1961 (or. ed. 1843).

Ibn Haldun, al-Muqaddima, (Beirut: Dār al-Ğīl, n.d.); Eng. transl. F. Rosenthal, The Muqaddimah, 3 vols (New York: Pantheon Books, 1958).

Ibn Ḥamdūn, al-Taḍkira al-Hamdūniyya, ed. Iḥsān ' ${ }^{\mathrm{C}} \mathrm{Abbās} \mathrm{Bakr}{ }^{\mathrm{c}} \mathrm{Abbās}$, 10 vols (Beirut: Dār Șādir, 1996).

Ibn Ḥawqal, Kitāb șūrat al-arḍ $=$ Liber imaginis terrae, ed. J. H. Kramers, (repr. Leiden: Brill, 1967 or. ed. 1938) (BGA, 2). French transl. by J. H. Kramers et G. Wiet, Configuration de la terre, 2 vols (Beirut: Commission internationale pour la traduction des chefs d'oeuvre-Paris : Maisonnuve and Larose, 1964-65).

Ibn Ḥiğğa al-Ḥamawī, Tamarāt al-awrāq (Beirut: Dār al-Ǧ̄̄l, 1407/1987).

Ibn Qutayba, ${ }^{c} U y \bar{u} n$ al-aḩbār, 4 vols in 2 (Beirut: Dār al-Kutub al${ }^{c}$ Ilmiyya, n.d.).

Ibn al-Uhuwwa, The Macālim al-Qurba fi ahkām al-hisba, ed. with abstract of contents, glossary and indices by R. Levy (London: Luzac; E. J. W. Gibb Memorial Series, n.s. XII, 1938).

al-Ibš̄ịīi, Šihāb al-Dīn, al-Mustatraf fì kull fann mustazraf, ed. Mufīd Muhammad Qumayḥa, 2 vols (Beirut: Dār al-Kutub al-'Ilmiyya, 1406/1986).

Al-Nīsāburī, Abū 1-Qāsim, ${ }^{c} U q a l \bar{a}^{\supset}$ al-mağānīn, ed. ${ }^{\mathrm{c}}$ Abd al-Amīr Muhannā (Beirut: Dār al-Fikr al-Lubnān̄i, 1990).

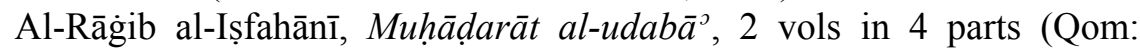


Intišārāt al-Maktaba al-Ḥaydariyya, 1415/1995).

Al-Šarīšīi, Šarh Maqāmāt al-Harīrī, ed. I. Šams al-Dīn, 3 vols (Beirut:

Dār al-Kutub al-c Ilmiyya, 1419/1998).

Al-Tanūh̄ī, Nišwār al-muhạdara wa-ahbār al-mudakara, ed. 'Abbūd al-

Šāliğī, 8 vols (Beirut: Dār Șādir, 1391/1973-1393/1973).

Al-Tawhīīī, Abū Hayyān, al-Imtă ${ }^{c}$ wa-l-mu ānasa, ed. Ahmad Amīn, Ahmad al-Zayn, 3 vols in 1 (Beirut: Manšūrāt al-Maktaba al- ${ }^{\mathrm{c}}$ Așriyya, n.d.).

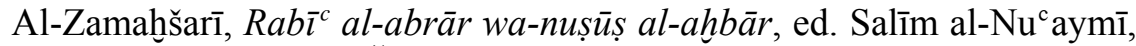
5 vols (Baghdad: al-Ğumhūriyya al- 'Irāqiyya, Wizārat al-Awqāf wa-1Šu ūn al-Dīniyya, [1976?]-[1982?]).

Secondary Studies

Basset, R., Mille et un contes, récits et légendes arabes, anthologie établie par René Basset, édition dirigée par Aboubakr Chraïbi, 2 vols (Paris: José Corti, 2005).

Bouyahia, C., La Vie littéraire en Ifriqiya sous les Zirides (Tunis: S.T.D., 1972).

Chauvin, V., Bibliographie des ouvrages arabes ou relatifs aux Arabes publiés dans l'Europe chrétienne de 1810 à 1885, 10 vols; vol. 6: Les Mille et une nuits (troisième partie) (Liège: Vaillant CarmanneLeipzig: Harrassowitz, 1902).

Dietrich, A., 'Éducation princière à la cour abbaside', in G. Makdisi, D. Sourdel, J. Sourdel-Thomine (eds.), L'Enseignement en Islam et en Occident au moyen âge: Communications présentées pendant la session des 25-28 octobre 1976 (Paris: Geuthner 1977, REI hors série, 13, 89-104).

Ghersetti, A., 'Firāsa and Intelligence. The Silly and the Intelligent in Arab Physiognomy', The Arabist. Budapest Studies in Arabic and Islam 17, 1996, Proceedings of the Colloquium on Logos, Ethos and Mythos in the Middle East and North Africa, Budapest, 18-22 Sept. 1995, 121-131.

Ghersetti, A., 'I paradigmi della stupidità: humq e hamqā nella letteratura d'adab', Annali di Ca' Foscari 32 (1993), S.O. 24, 83-95.

Ghersetti, A., 'À la recherche de nourriture': étude des thèmes liés aux pique-assiettes (țfayliyyūn) dans la littérature d'adab, al-Qantara 25 (2004), 433-462.

Goldziher, I., Muslim Studies, ed. S. M. Stern, transl. C. R. Barber, S. M. Stern, 2 vols (London: Allen and Unwin, 1967; or ed. Muhammedanische Studien, Halle, 1889-90).

Günther, S. 'Advice for Teachers: The 9th-Century Muslim Scholars Ibn 
Sahnun and al-Jahiz on Pedagogy and Didactics', in Sebastian Günther (ed.), Ideas, Images and Methods of Portrayal. Insights into Classical Arabic Literature and Islam. Islamic History and Civilization. Studies and Texts, vol. 58 (Leiden-Boston: Brill, 2005, 89-128).

Günther, S., 'Be Masters in That You Teach and Continue to Learn: Medieval Muslim Thinkers on Educational Theory', Comparative Education Review, 50/3 (2006), 367-388.

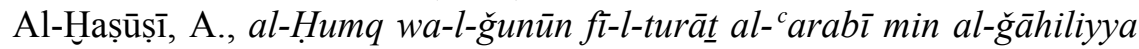
ilā nihāyat al-qarn al-rābic ${ }^{c}$, (Cairo: al-Hay ${ }^{\circ}$ a al- ${ }^{\mathrm{c}}$ Mișriyya al- ${ }^{\mathrm{A}} \overline{\mathrm{A}} \mathrm{mma}$ li-1-Kitāb, 1992).

Hirschfeld, H., 'A Volume of Essays by al-Jāhiiz, in A Volume of Oriental Studies Presented to Edward G. Brown on his 60th Birthday, 7 February 1922, ed. T. W. Arnold and Reynold A. Nicholson (Cambridge: Cambridge University Press, 1922).

Jackson, S. A., 'Discipline and Duty in a Medieval Muslim Elementary School: Ibn Ḥajar al-Haytamī's Taqrīr al-maqāl', in E. J. Lowry, D. J. Stewart and S. M. Toorawa. (eds.), Law and Education in Medieval Islam. Studies in Memory of Professor George Makdisi (Warminster: Gibb Memorial Trust, 2004), 18-32.

Kadi, W., 'Education in Islam-Myths and Truths', in W. Kadi and V. Billeh (eds.), Islam and Education. Myths and Truths (Chicago: University of Chicago Press, 2007, 5-18).

Lecomte, G., 'Les livre des règles de conduite des maîtres d'école par Ibn Sạ̣nūn', Revue des Etudes Islamique, 1953, 77-105.

Makdisi, G., 'Muslim Institutions of Learning in Eleventh-Century Baghdad', Bulletin of the School of Oriental and African Studies 24 (1961), 1-56.

Makdisi, G., The Rise of Colleges (Edinburgh: Edinburgh University Press, 1981).

Melchert, C., 'The Etiquette of Learning in the Early Islamic Study Circle', in J. E. Lowry, D. J. Stewart and S. M. Toorawa (eds.), Law and Education in Medieval Islam. Studies in Memory of Professor George Makdisi, (Warminster: Gibb Memorial Trust, 2004), 33-44.

Mez, A., The Renaissance of Islam, trans. Salahuddin Khuda Bukhsh and D.S. Margoliouth (London: Luzac, 1937; repr. New York, AMS, 1975; or. ed. Die Renaissance des Islams, 1922).

Pellat, Ch., Le Milieu bașrien et la formation de Ğāhiz (Paris: Librairie d'Amérique et d'Orient Adrien-Maisonneuve, 1953).

al-Qasimy, S., Dictionnaire des métiers damascains, édité et précédé d'une introduction par Zafer al-Qasimy, vol. 1, (Paris-La Haye: 
Mouton, 1960).

Sadan, J., "'An Admirable and Ridiculous Hero": Some Notes on the Bedouin in Medieval Arabic Belles Lettres, on a Chapter of Adab by al-Râghib al-Ișfahânî, and on a Literary Model in which Admiration and Mockery Coexist', Poetics Today, 10 (1989), 471-492

Vadet, J. Cl., 'Ibn Shubruma', Encylopaedia of Islam, 2nd ed., 3: 938.

Zakharia, K., 'Le Savoir et ses dupes dans les Histoires des idiots et des sots d'Ibn al-Ğawzī', Bulletin d'études orientales 47 (1995), 217-233. 